\title{
KEJADIAN MASTITIS SUBKLINIS PADA INDUK SAPI PERAH LAKTASI DI DESA SUMBERSARI KECAMATAN UDANAWU KABUPATEN BLITAR
}

\author{
The Prevalence of Subclinical Mastitis on Dairy Cows at Sumbersari Sub Distric, Udanawu \\ Distric, Blitar Regency
}

\author{
Anna Lidiyawati' ${ }^{1}$ Binti Khopsoh ${ }^{1}$, dan Riska Faradila ${ }^{1}$ \\ 1Fakultas Ilmu Eksakta Prodi Peternakan Universitas Nahdlatul Ulama Blitar \\ Email: lidiyawatianna@gmail.com
}

\begin{abstract}
ABSTRAK
Penelitian ini bertujuan untuk mendeskripsikan jumlah induk sapi perah laktasi yang terindikasi mastitis subklinis di Desa Sumbersari Kecamatan Udanawu Kabupaten Blitar. Metode survei dan wawancara dilakukan terhadap 12 peternak sapi perah dengan kriteria responden adalah peternak sapi perah yang telah memelihara sapi perah selama 2 tahun. Jumlah sapi perah yang diperiksa menggunakan uji mastitis California (CMT) adalah 136 ekor dan dilakukan wawancara terhadap peternak tentang cara pencegahan yang sudah dilakukan dalam mengurangi kejadian mastitis subklinis. Data yang terkumpul kemudian dianalisa menggunakan Analisa deskriptif. Hasil penelitian menunjukkan $41,91 \%$ induk laktasi ternyata terindikasi mastitis subklinis. Sisanya 58,08 $\%$ induk laktasi dalam kondisi yang sehat tidak ditemukan mastitis klinis. Pencelupan antiseptik pasca pemerahan dilakukan kepada 20 induk sapi sebagai perlakuan sedangkan sisanya 116 ekor hanya dilakukan pembilasan. Belum ditemukan peternak sapi perah yang memberikan treatment pada masa kering dan cek mastitis secara berkala, peternak hanya berfokus pada penambahan pakan untuk induk sebagai persiapan sebelum melahirkan. Untuk mengurangi kejadian mastitis maka perlu adanya edukasi ditingkat peternak berkaitan dengan penanganan susu, teat dips, treatment masa kering dan tes mastitis secara berkala.
\end{abstract}

Kata kunci: Celup Putting, Mastitis, Subclinic, Sumbersari, Perlakuan Masa Kering

\begin{abstract}
Mastitis is udder inflammation and the most prevalent disease in dairy herd it's responsible for several production effect such as reduce revenue for farmer. The aim of this study is to discription how many sub clinis and clinic mastitis case occurs in Sumbersari Districs. There are 12 farmer refered to 2 years experience in dairy cows as responden and 136 heads of dairy cow lactation were examinated againt mastitis with California Mastitis Test (CMT). Data were analyzed discriptively. The result showed that the percentage of cows with sub clinical case reached $41,91 \%$ and $58,08 \%$ negative. Treatment of dipping post-milking with antiseptic were used for 20 heads and 116 heads treat with rinse water to againt mastitis. This study revealed that no farmers tried to control mastitis using dry cow therapy teat dips respectively. In conclusion to reduce the prevalence of subclinic mastitis farmers in the study area need to be trained on good milking practice including reguler use of teat dips, aplication on dry cow theraphy and subclinical mastitis test.
\end{abstract}

Keywords: Teat dips, Mastitis, Subclinic, Sumbersari, Dry Cow Treatment

\section{PENDAHULUAN}

Mastitis didefinisikan sebagai radang pada kelenjar susu. Kejadian mastitis pada peternakan sapi perah sering diidentikkan dengan fenomena gunung es. Sepertinya tidak ada namun kenyataannya bisa menjadi bumerang. Apabila suatu peternakan sapi perah terindikasi terkena mastitis maka kerugian yang ditimbulkan antara lain: Penurunan produksi susu per kwartir per hari antara 9\%-45,5\% (Sudarwanto, 1999). Penurunan kualitas susu yang mengakibatkan 
penolakan susu mencapai 30\%-40\% dan penurunan kualitas hasil olahan susu (Hamman \& Fehlings, 2002; Hamman, 2004). Peningkatan biaya perawatan dan pengobatan serta pengafkiran ternak lebih awal (Seegers et al., 2003; Shim et al., 2004). Terkontaminasinya susu dengan antibiotik (Mpatswenumugabo et al., 2017).

Ada dua jenis mastitis yaitu mastitis klinis (mastitis dengan gejala klinis yang jelas) dan mastitis subklinis (mastitis dengan gejala klinis yang tidak nampak). Pada kasus mastitis subklinis tidak nampak perubahan fisik pada ambing dan susu namun terjadi penurunan produksi dan perubahan komposisi susu akibat bakteri patogen apabila dilakukan uji laboratorium maka akan terlihat jenis bakteri patogennya. Bakteri penyebab mastitis antara lain Str. agalactiae, Str. dysgalactiae, S. uberis, Str. zoopidermicus. Menurut Subronto (2003) bakteri lain yang bisa menyebabkan mastitis adalah Escherichia coli (E. coli), E. feundeii, Aerobacter aerugenes dan Klebsiella pneumoniae.

Saraswati (2013) menyatakan bahwa kejadian mastitis subklinis dari tahun 1983-2018 di Indonesia berada di kisaran 65-90\%. Dan seringkali mastitis subklinis akan berubah menjadi mastitis klinis bila tidak ditangani dengan tepat. Pemberian antibiotik dianggap sebagai pilihan jitu dalam mengobati mastitis namun ada resistensi bakteri akibat penggunaan antibiotik menjadi masalah tersendiri. Sehingga tindakan pencegahan mastitis atau mastitis merupakan cara yang dipandang efektif dalam menghadapi penyakit mastitis. Dalam upaya mengetahui penerapan mastitis kontrol yang dilakukan peternak terhadap kejadian mastitis maka dilakukan penelitian survei di daerah Sumbersari sebagai salah satu sentra peternak sapi perah di Blitar.

\section{METODE}

Penelitian ini menggunakan metode survei. Pengambilan sampel peternak berdasarkan kriteria minimal sudah 2 (dua) tahun beternak sapi perah. Sebanyak 136 ekor sapi perah sedang laktasi diperiksa menggunakan uji California Mastitis Test/CMT (Sudarwanto, 1999) selain itu dilakukan pengamatan langsung perlakuan pasca pemerahan dan wawancara tentang tindakan pencegahan penyakit mastitis.

\section{HASIL DAN PEMBAHASAN}

\section{Deteksi Mastitis}

Dari tabel 1 diketahui bahwa persentase kejadian mastitis subklinis di desa Sumbersari masih cukup tingi yakni 41,91\%, hal ini merupakan peringatan agar peternak sapi perah mulai waspada terhadap bahaya mastitis. Pencelupan puting sebelum dan sesudah pemerahan sangat direkomendasikan agar kejadian mastitis subklinis tidak berubah menjadi mastitis klinis (Sampion et al., 2008). Kejadian mastitis subklinis seringkali tidak terdeteksi secara kasat mata karena dari luar ambing tampak normal namun sebenarnya sudah terjadi infeksi karena mikroorganisme patogen. Peternak memerlukan alat bantu untuk mendeteksi adanya mastitis subklinis. Indikator penting dalam mendiagnosa mastitis adalah adanya peningkatan jumlah sel somatik dalam air susu (Sudarwanto, 1999).

Tabel 1. Kejadian mastitis yang mempengaruhi poduktivitas sapi perah

\begin{tabular}{ccccc}
\hline Area & $\begin{array}{c}\text { Jumlah sapi } \\
\text { yang di test } \\
\text { (ekor) }\end{array}$ & $\begin{array}{c}\text { Jumlah CMT } \\
\text { positive (ekor) }\end{array}$ & $\begin{array}{c}\text { Jumlah CMT } \\
\text { negative (ekor) }\end{array}$ & $\begin{array}{c}\text { Persentase } \\
\text { Positive } \\
\text { mastitis (\%) }\end{array}$ \\
\hline Sumbersari & 136 & 57 & 79 & 41,91 \\
\hline
\end{tabular}


Ada beberapa alternatif pengujian mastitis yakni perhitungan sel somatik baik secara langsung misalnya breed, fossomatik, coulter counter, tas, laser dan menghitung sel somatik secara tidak langsung antara lain dengan menggunakan alat California Mastitis Test (CMT) yang pada prinsipnya adalah dimana pembacaan derajat mastitis berdasarkan kekentalan seperti yang tertera pada gambar 1 dibawah ini atau berdasarkan perubahan $\mathrm{pH}$ dengan menggunakan bromtymol blue / bromtymol purple dimana susu yang dicurigai mastitis memliki $\mathrm{pH}>6.8$.

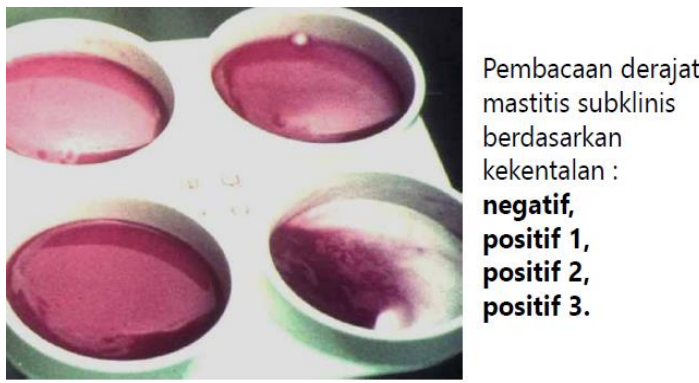

Gambar 1. Pengujian Mastitis menggunakan CMT (Marshall, 1993)

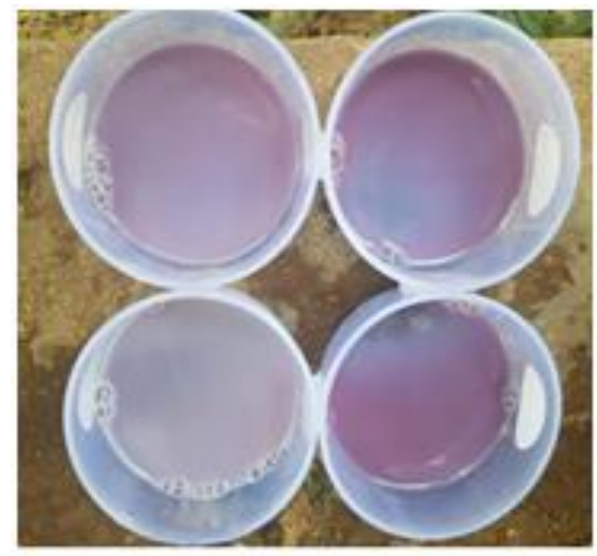

Gambar 2. Pengujian CMT penelitian

Tabel 2. Kasus Mastitis dan posisi puting yang terdeteksi positif

\begin{tabular}{cccccc}
\hline \multirow{2}{*}{ Lokasi } & Jenis & \multicolumn{4}{c}{ Posisi puting } \\
\cline { 3 - 6 } & mastitis & Depan kanan & Depan kiri & $\begin{array}{c}\text { Belakang } \\
\text { kanan }\end{array}$ & $\begin{array}{c}\text { Belakang } \\
\text { kiri }\end{array}$ \\
\hline Desa & Subklinis & 45 & 36 & 57 & 34 \\
Sumbersari & Negatif & 91 & 100 & 79 & 102 \\
\hline
\end{tabular}

Pada Tabel 2 diketahui bahwa semua posisi puting beresiko terkena mastitis, baik kontaminasi lingkungan dengan mikroba patogen seperti Escheria coli (Zalizar et al., 2013) maupun bakteri infeksius seperti Streptococcus agalactie dan Staphylococus aurreus. Hal ini terlihat dari jumlah puting yang terkena mastitis hampir sama di semua posisi.

\section{Pencegahan Mastitis}

Di Desa Sumbersari sudah dilakukan upaya untuk mencegah mastitis. Dari 12 peternak sapi perah ada yang memberikan perlakuan sebelum dan setelah pemerahan yakni dengan pencelupan antiseptik iodin. Namun sebagian besar peternak di desa Sumbersari hanya melakukan pembilasan air dan mengelap puting setelah selesai pemerahan. Hal ini sejalan dengan Mahardika (2016) yang menyatakan bahwa perlakuan teat dips bisa menurunkan jumlah sel somatik pada air susu sapi perah. 
Perlakuan teat dips setelah pemerahan dilakukan dengan menggunakan antiseptik iodine. Senyawa povidone iodinepada atiseptik disinyalir mampu menghambat pertumbuhan mikroorganisme patogen. Teat dipping sebagai upaya pencegahan mastitis selain menggunakan antiseptik kimia juga bisa menggunakan ekstrak tanaman obat.

Tabel 3. Perlakuan setelah pemerahan

\begin{tabular}{clcc}
\hline \multirow{2}{*}{ Lokasi } & Jenis mastitis & \multicolumn{2}{c}{ Perlakuan setelah pemerahan } \\
\cline { 3 - 4 } & & $\begin{array}{c}\text { Dipping dengan } \\
\text { antiseptik (ekor) }\end{array}$ & $\begin{array}{c}\text { Dipping dengan air } \\
\text { (ekor) }\end{array}$ \\
\hline \multirow{2}{*}{ Desa Sumbersari } & Subklinis & 20 & 37 \\
& Negative & 12 & 67 \\
\hline
\end{tabular}

Beberapa tanaman obat yang diketahui mempunyai aktivitas antibakteri telah banyak dimanfaatkan. Seperti dekok kersen (Muntingia callabura L) dengan konsentrasi 20\% mampu menurunkan tingkat kejadian mastitis sebanyak $80 \%$, ekstrak meniran dan salep daun sirih mampu menghambat Staphylococcus aureus dan Escherichia coli (Zalizar et al., 2015). Meniran sebagai imunomodulator (Amirghofran et al., 2000) dan senyawa flavanoid Phylantus niruri mampu meningkatkan kekebalan tikus terhadap infeksi bakteri penyebab mastitis yakni Streptococcus agalactiae (Zalizar, 2013).

Namun pencegahan mastitis baik yang berupa deteksi mastitis secara berkala maupun treatment masa kering sebagai upaya mengontrol mastitis belum dilakukan oleh peternak sapi perah di desa Sumbersari. Peternak hanya fokus untuk menambah jumlah pakan untuk persiapan melahirkan.

\section{KESIMPULAN}

Kejadian mastitis subklinis di peternakan sapi perah di Desa Sumbersari Kecamatan Udanawu Kabupaten Blitar masih cukup tingi yakni 41,91\%. Dengan resiko kontaminasi berada pada semua posisi puting. Namun sudah ada peternak yang melaksanakan pencelupan puting sebelum dan sesudah pemerahan sebagai upaya pencegahan terhadap mastitis. Walaupun deteksi mastitis dan kontrol mastitis terutama treatment pada masa kering belum dilakukan secara rutin. Sehingga disarankan untuk melakukan edukasi kepada peternak agar mampu melakukan deteksi dan kontrol mastitis secara berkala.

\section{UCAPAN TERIMA KASIH}

Terima kasih penulis haturkan kepada LPPM UNU BLITAR yang telah mendanai penelitian ini dan para peternak sapi perah yang ada di Desa Sumbersari serta rekan-rekan dosen UNU BLITAR yang telah memberikan semangat dan motivasi sehingga pelaksanaan penelitian ini dapat berjalan lancar. Tak lupa penulis haturkan terima kasih kepada Jurusan Peternakan Politeknik Negeri Jember yang telah memberikan kesempatan kepada kami untuk mempresentasikan hasil penelitian kami dalam acara Dies Natalis ke-32 Politeknik Negeri Jember.

\section{DAFTAR PUSTAKA}

Amirghofran, Z., Baktit, M., A., \& Karimi, M., H. (2000). Evaluation of the immunomodulatorry effect of five herbal plants. Journal of Etnopharmacology, 72, 167-172.

Hamman, J. \& Fehlings, K. (2002). Leitlinien zur Bekaempfung der Mastitis des Rindes als 
Bestandsproben. 4. Auflage, DVG-Verlag, Giessen.

Hamman, J. (2004). Nur Gesunde kuehe produzieren “Gesunde” Milch. DMZ 25: 36-39.

Mahardika, H. A. (2016). Pengaruh suhu air pencucian ambing dan teat dipping terhadap jumlah produksi, kualitas dan jumlah sel somatik susu pada peternakan sapi peranakan Friesian Holstein. Buletin Peternakan, 40(1), 11-19.

Mpatswenumugabo, J. P., Bebora, L. C., Gitao, G. C., Mobegi, V. A., Iraguha, B., Kamana, O., \& Shumbusho, B. (2017). Prevalence of subclinical mastitis and distribution of pathogens in dairy farms of Rubavu and Nyabihu Districts, Rwanda. Journal of Veterinary Medicine, 1-8. https://doi.org/10.1155/2017/8456713

Saraswati, D. (2013). Daya Hambat Antibiotik terhadap Bakteri dari Susu Kambing Peranakan Ettawah (PE): Normal, Mastitis, Subklinis, dan Klinis. Skripsi. Yogyakarta: Fakultas Kedokteran Hewan, Universitas Gadjah Mada.

Seegers, H., Fourichon, C., \& Beaudeau, F. (2003). Production effects related to mastitis and mastitis economics in dairy cattle herds. Veterinary Research. 34(2003), 475-491. https://doi.org/10.1051/vetres:2003027

Shim, E. H., Shanks, R. D., \& Morin, D. E. (2004). Milk loss and treatment costs associated with two treatment protocols for clinical mastitis in dairy cows. Journal of Dairy Science 87, 27022708. https://doi.org/10.3168/jds.S0022-0302(04)73397-4

Subronto. (2003). Ilmu Penyakit Ternak I. Yogyakarta: Gajah Mada Univ. Press.

Sudarwanto, M. (1999). Usaha Peningkatan Produksi Susu melalui Program Pengendalian Mastitis Subklinis. Orasi Ilmiah, 22 Mei 1999. Fakultas Kedokteran Hewan. Institut Pertanian Bogor.

Zalizar, L. (2013). Flavanoids of Phylanthus Niruri as Immunomodulators. A prospect to animal disease control. ARPN Journal of Science and Technology, 3(5), 529-532.

Zalizar, L., Relawati, B., \& Ariandi, B. Y. (2013). Potensi produksi dan ekonomi biogas serta implikasinya pada kesehatan manusia, ternak dan lingkungan. Jurnal Ilmu-ilmu Peternakan, 23(3), 32-40.

Zalizar, L., Sujono, \& Suyatno. (2015). Daya Antibakteri Salep Herbal (Piper betle dan Phyllanthus niruri) terhadap Bakteri Staphylococcus aureus dan Eschericia coli. Laporan Penelitian Block Grant. Malang: Fakultas Pertanian - Peternakan. Universitas Muhammadiyah Malang. 